\title{
BRITISH ASSOCIATION MEETING IN SHEFFIELD
}

$\mathrm{D}^{4}$ RING August 29-September 5 this ycar, the British Association will hold its annual meeting in Sheffield. Sheffield has many advantages as a place of meeting for the British Association. One of the major centres of industry, exceedingly busy and dependent in almost every branch on the continuous application of scientific discovery, a visit provides a fine stimulus to any scientist; but, unlike most industrial centres, Sheffield is a surprisingly pleasant city, especially on its west and south sides, and it is set in surroundings of great natural beauty immediately accessible by bus or even on foot. Full advantage of these is being taken in the arrangements for the meeting. It is perhaps singularly appropriate that Sheffield should be chosen for the meeting this year, for a century ago, at the Choltenham meeting in 1856, Bessemer made the first public announcement of his revolutionary steel-making process, for which shortly after he set up his own works in Sheffield.

The accommodation for the meeting will be divided between two centres. In the middle of the city, within easy reach of the railway stations and served by public transport from every district, will be the Reception Room (the Central Technical School-in the former Firth College). Within a few yards of this are the City Hall, where the large general meetings will be held, and the Cutlers' Hall, which will provide a convenient social centre. The section meetings will all be held in the University area, mostly in the University buildings. These are within easy walking distance of the Reception Centre; but, for the meeting, special buses for members will circulate between the Reception Centre and the section rooms, in addition to the regular public transport.

The inaugural meeting on the evening of Wednesday, August 29, will, as on a number of such occasions, be preceded by a short degree congregation, when the chancellor of the University, the Eaid of Halifax, will confer honorary doctorates on Sir Raymond Priestley, president of the Association, and on Sir George Thomson and Sir Charles Goodeve, the presidents of Sections $A$ and $B$, respectively. The president's address will be on 'Twentieth Century Man against Antarctica", a subject mos's apposite and topical in view of the attention which is focused this year on the further exploration of the Antarctic by several important expeditions. Sir Raymond Priestley can speak with authority on this, because not only did he accompany both Shackleton and Scott to the Antarctic, but also he is still intimately associated with Antarctic exploration and development.

The two evening discourses will be on "Ihe Growth of Biochemistry", by Prof. F. G. Young (August 31) and "The International Geophysical Year", by Prof. Sydney Chapman, chairman of the International Committee organizing the International Geophysical Year (September 3)-another subject of great topical interest.

It is, however, a prime object of the Association "to bring the objects of science more before the public eye". Many citizens who may be hesitant immediately to become members may yet wish to know more of what science means and to see at close quarter's some of its leading figures. With them in mind, two further illustrated evening lectures have been arranged, freely open to the public, on "Antarctic Adventure", by Sir Raymond Priestley (August 30), and "The Future Development of Atomic Energy", by Sir John Cockcroft (September 4).

All these meetings will be held in the Main (Oval) Hall of the City Hall, which, seating 2,700, should accommodate the audiences in comfort.

But the heart of the gathering is in the meetings of the sections, and here will be encountered the richness and variety that have so long characterized the British Association. 'To summarize the very varied subjects that will be dealt with in presidential addresses and sectional communications would need a separate article. Here it may suffice to say that, while most aspects of scientific endeavour seem to be included, there will be, as is appropriate in a major centre of industry, a slight but appreciable emphasis on matters of industrial and technological importance, an emphasis reflected even in the proceedings of Section $\mathrm{H}$, the general theme of which is to be "The Primitive Technology of Glass and Metals".

As in previous years, there will be an official service in Sheffield Cathedral on the Sunday morning, and other churches will hold special services. For the Sunday evening, the Local Committee has arranged for members a concert in the City Hall by the Hallé Orchestra and the Sheffield Philharmonic Choir, under Sir John Barbirolli and Mr. Herman Lindars.

A number of exhibitions have been arranged for the meeting, including one of polar rations, one of scientific glassware, and special displays at the City Museum and at the Graves Art Gallery, where there will also be a demonstration of the processes of picture restoration on an 'open evening'. It is hoped to arrange a display in honour of the Bessemer centenary, and, following the excellent lead given at Bristol, there will be an exhibition of "Science in Schools", organized by Mr. Stanley Moffett, director of education for Sheffield, and science masters and mistresses throughout the region. It is hoped to make this exhibition a fully 'live' show with most of the demonstrations and experiments actually working. A completely new departure will be a special exhibition of books about science arranged by the National Book League and staged in the Central Library. The professional scientist can generally find and assess the worth of technical books in his own field; but it is seldom that he can tell a lay friend where to find a book that explains the essentials in simple language-and outside his own field he is often quite lost. Here should be at least one answer to a difficult question, for which a great many members, scientists and laymen alike, may well be grateful. The regular showings of scientific films, begun in Bristol, will be continued in Sheffield in the convenient and well-equipped Library Theatre. Visitors to Sheffield will also be invited to inspect, in the same building, the Commercial and Technical Section of the Public Library, which provides a very 
important service for industry, commerce and the student.

The problem of housing the large number of members expected has been carefully studied. In particular, the whole accommodation of the University halls of residence and of the training colleges throughout the area has been reserved. Several of these are very recently built and are fine examples of collegiate architecture. Some are in former great houses, such as Wentworth Woodhouse, magnificently situated and of great historic interest as well as substantial comfort. Special bus services, free to residents, will run at appropriate times between the more distant of these and the meeting centres. Members wishing to stay in hotels should make early bookings. Arrangements have also been completed for ample private accommodation for those preferring it.

The main catering centre will be the lower floor of the City Hall; here a large restaurant with both cafeteria and waitress service will enable members to take lunch and other meals close to the Reception Centre and to the main bus station for excursions. Light refreshments will be available also in the University Union, there will be coffee points near all section rooms, and a mobile canteen on the Associa. tion's bus station will supply packed meals on demand.

Some 140 general and sectional excursions have been planned, and a member who so wishes will have little difficulty in getting, within the week, a general idea of the heavy and light industries of the area and in appreciating the glorious countryside in which they are set. A special bus station, within easy reach of the University and Reception Centre, will be brought into use solely for the Association, and nearly every excursion will start and end there.
Under the title of "Sheffield and its Region", an extensively illustrated scientific survey of some $\mathbf{3 3 0}$ pages by twenty-seven contributors under the editorship of Prof. D. L. Linton will be presented to members attending the meeting. In three parts, the first gives an account of what may be termed the natural history, pre-history and history of the region; the second treats of "The City of Sheffield" and deals with aspects of its economic development, with the growth of its social institutions, with its contributions to art and science, and with its present characteristics and plans for the future. The third part, under the heading "The Region Today", deals with some of the industries by which the inhabitants of the region gain their livelihood and with the towns, outside Sheffield, in which they live.

The community of Sheffield looks forward eagerly to receiving its distinguished visitors, who are assured of a cordial welcome. This will be the third time that the Association has met in Sheffield. The first was in 1879, with Henry Clifton Sorby as one of the local secretaries, when Crookes demonstrated many of the properties of cathode rays. That year was an important one in Sheffield, for a few weeks after the members of the Association had dispersed, Prince Leopold, youngest son of Queen Victoria, opened Mark Firth's foundation, Firth College, from which the University has grown. The second occasion was in 1910. The depression in the Sheffield industries during the inter-war years probably accounts for the long interval between the second and the present meetings. The Local Committee now hopes that, in a city and region so devoted to the applications of science, there may be a large enrolment of local members, and trusts that the occasion may prove memorable both in Sheffield and to all those who visit it.

\title{
LEWIS EVANS (I700-56): A SCIENTIST IN COLONIAL AMERICA
}

\author{
By Prof. GEORGE W. WHITE \\ Department of Geology, University of Illinois
}

\begin{abstract}
EWIS EVANS, who died two hundred years ago $\mathcal{L}$ on June 11, earned his living as a professional engineer and cartographer; he was a geographer and natural scientist as well. Ho was born in 1700 at Llangwnadl, near Pwlhelli, Carnarvonshire, Wales ${ }^{1}$. It is not known how and when he came to Colonial America; but in 1736 he was a surveyor and mapmaker in Philadelphia. He had associations with Benjamin Franklin, purchased books from him, and probably did some drafting and engraving for him. He travelled extensively with John Bartram, Botanist to the King; gave much information to Peter Kalm, the Swedish scientific traveller; and provided geographical and other service to Governor Thomas Pownall. These men and others of the time quote Evans's scientific opinions in their writings approvingly and at some length.

Evans made valuable observations on plants, animals, and meteorology, and in other fields of science. His knowledge of astronomy and physics ('natural philosophy'), including electricity, was such that he gave series of lectures on these subjects in
\end{abstract}

1751 in Philadelphia, Newark and New York. Thirteen lectures made up the series in New York. His maps of the middle Atlantic Colonies went through more than twenty editions, although most of them were printed without credit to Evans. His topographical descriptions formed the physiographical groundwork for American geographical description (again usually without credit) for more than fifty years. His most important scientific contributions were his penetrating geological observations about eastern North America and the respectable theories, some of them far in advance of his time, that he based on them ${ }^{2}$.

Evans travelled extensively through the middle Atlantic Colonies across the Coastal Plain, Piedmont, the folded Appalachian Mountains, and made at least one journey across the Appalachian Plateau to Lake Ontario. These observations were the basis of his maps of 1749 and $1752^{3}$ of Pennsylvania and of his famous map of the Middle Atlantic Colonies of $1755^{4}$. In his journal ${ }^{5}$ of a trip in 1743 to Lake Ontario (published by Governor Thomas Pownall in 1776), 